\title{
Diagnostic Principles of Peri-Implantitis: a Systematic Review and Guidelines for Peri-Implantitis Diagnosis Proposal
}

\author{
Ausra Ramanauskaite1, Gintaras Juodzbalys ${ }^{2}$ \\ ${ }^{1}$ Clinic of Dental and Oral Pathology, Lithuanian University of Health Sciences, Kaunas, Lithuania. \\ ${ }^{2}$ Department of Maxillofacial Surgery, Lithuanian University of Health Sciences, Kaunas, Lithuania.
}

\author{
Corresponding Author: \\ Ausra Ramanauskaite \\ Department of Dental and Oral Pathology \\ Lithuanian University of Health Sciences \\ Eiveniu 2, LT- 50009, Kaunas \\ Lithuania \\ Phone: +37067813934 \\ E-mail: ausra.ramanauskaite@gmail.com
}

\begin{abstract}
Objectives: To review and summarize the literature concerning peri-implantitis diagnostic parameters and to propose guidelines for peri-implantitis diagnosis.

Material and Methods: An electronic literature search was conducted of the MEDLINE (Ovid) and EMBASE databases for articles published between 2011 and 2016. Sequential screening at the title/abstract and full-text levels was performed. Systematic reviews/guidelines of consensus conferences proposing classification or suggesting diagnostic parameters for peri-implantitis in the English language were included. The review was recorded on PROSPERO system with the code CRD42016033287.

Results: The search resulted in 10 articles that met the inclusion criteria. Four were papers from consensus conferences, two recommended diagnostic guidelines, three proposed classification of peri-implantitis, and one suggested an index for implant success. The following parameters were suggested to be used for peri-implantitis diagnosis: pain, mobility, bleeding on probing, probing depth, suppuration/exudate, and radiographic bone loss. In all of the papers, different definitions of periimplantitis or implant success, as well as different thresholds for the above mentioned clinical and radiographical parameters, were used. Current evidence rationale for the diagnosis of peri-implantitis and classification based on consecutive evaluation of soft-tissue conditions and the amount of bone loss were suggested.

Conclusions: Currently there is no single uniform definition of peri-implantitis or the parameters that should be used. Rationale for diagnosis and prognosis of peri-implantitis as well as classification of the disease is proposed.
\end{abstract}

Keywords: dental implant; diagnosis; endosseous dental implantation; peri-implantitis.

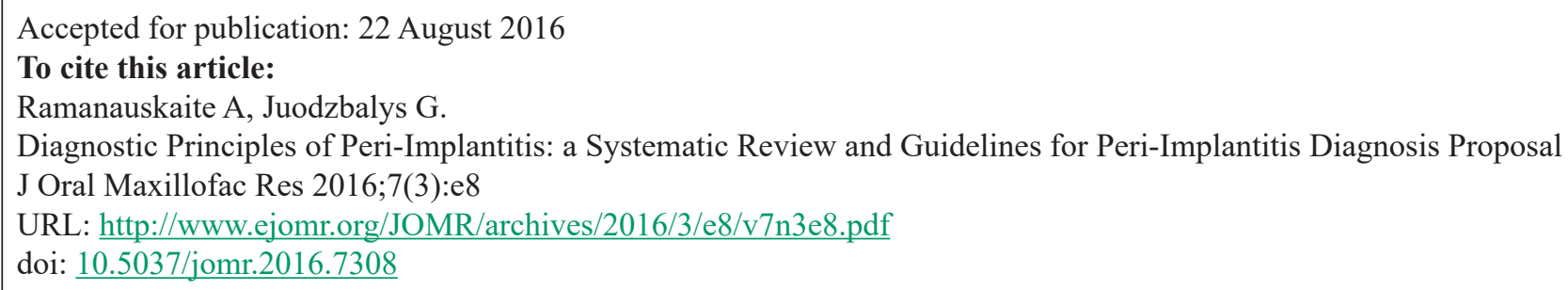




\section{INTRODUCTION}

Replacing missing teeth with titanium dental implants has become a routine procedure. High survival rates, ranging from $95 \%$ to $98 \%$ over a period of 10 years has been reported and have encouraged clinician to consider this type of oral rehabilitation [1, 2$]$. However, survival rates does not take into account the presence of biological complications, and, despite the remarkably high survival rate of dental implants, there are increasing numbers of patients presenting with peri-implant diseases [ [3]].

Peri-implant diseases have been classified as either peri-implant mucositis or peri-implantitis [4]. Periimplant mucositis has been defined as soft tissue inflammation around a functioning dental implant with bleeding on probing (BOP), and per-implantitis is distinguished by accompanying loss of supporting marginal bone past normal bone remodelling [4]. If not diagnosed and not properly managed, peri-implant diseases may lead to loss of the implant []ㅡ.

Mombelli et al. [] described peri-implant diseases as infectious diseases that shares features with chronic periodontitis. Currently, although the hypothesis of bacterial infection due to plaque accumulation as the etiological factor is still accepted, it appear to be a multifactorial disease, where so-called combined factors (patient-, surgical-, and prosthetic-related) may contribute to the development and severity of the pathosis [7-10].

A recent systematic review and meta-analysis of implants after at least 5 years of functioning reported a prevalence rate of peri-implant mucositis of $63.4 \%$ of individuals and $30.7 \%$ of implants and a rate of peri-implantitis of $18.8 \%$ of individuals and $9.6 \%$ of implants [11]. A systematic review by Mombelli et al. [12] indicated the prevalence of peri-implantitis seems to be in order of $10 \%$ implants and $20 \%$ patients during 5 - 10 years after implant placement, but the reported figures are rather variable, not easily comparable, because of different case definitions, the differential diagnosis, the chosen thresholds for probing depths (PDs) and bone loss.

Lacking similar diagnostic methods, classification for peri-implantitis often leads to confusion in diagnosis, making it is hard to determine the prevalence of the disease and the extent of the pathology and prognosis, which in turn makes it hard for the clinician to decide whether the implant can be treated or has failed and must be removed. The purposes of this review article was to review and summarize the literature concerning peri-implantitis diagnostic parameters and to propose rationale for diagnosis and prognosis of peri-implantitis.

\section{MATERIAL AND METHODS Protocol and registration}

The methods of the analysis and inclusion criteria were specified in advance and documented in a protocol. The review was registered in PROSPERO, an international prospective register of systematic reviews. The protocol registration number: CRD42016033287 can be accessed at:

http://www.crd.york.ac.uk/PROSPERO/display record.asp? ID=CRD42016033287

The reporting of this systematic analysis adhered to the Preferred Reporting Items for Systematic Review and Meta-Analyses (PRISMA) Statement [13].

\section{Focus question}

The following focus question was developed according to the population, intervention, comparison, and outcome (PICO) study design:

What are the parameters/guidelines suggested for diagnosing peri-implantitis with respect to clinical (including BOP and/or PD and/or plaque index) and/ or radiological measurements who can be applied for the patients having osseointegrated rough-surface, solid screw-type implant that presented with signs of peri-implantitis?

\section{Types of publications}

The review included systematic reviews/guidelines of consensus conferences in the English language published between January 1, 2011, and February 1, 2016. Letters, editorials, PhD theses, and abstracts were excluded.

\section{Information sources}

The search strategy incorporated the examination of electronic databases, supplemented by hand searches. A search was conducted on the MEDLINE (Ovid) and EMBASE databases. Additionally, a hand search was conducted in the following journals: "Clinical Oral Implants Research", "Clinical Implant Dentistry and Related Research", "European Journal of Oral Implantology", "Implant Dentistry", "International Journal of Oral \& Maxillofacial Implants", "International Journal of Periodontics and Restorative Dentistry", "Journal of Clinical Periodontology", "Journal of Oral Implantology", "International Journal of Oral and Maxillofacial Surgery", "Journal of Periodontology", "Journal of Prosthetic Dentistry", "Open Dentistry Journal", "Journal of Implants and 
Advanced Clinical Dentistry".

The references of each relevant study were screened to discover additional relevant publications and to improve the sensitivity of the search.

\section{Search}

The MEDLINE and EMBASE resource databases were explored through advanced searches. The keywords and search inquiries used during the primary stage were as follows: ("peri-implantitis" OR "peri-implant complication" OR "peri-implant infection" OR ("implant" AND "failure) AND ("diagnosis" OR "classification" OR "guidelines" OR "severity" OR "success" OR "failure"). The choice of keywords was intended to be broad to collect as much relevant data as possible without relying on electronic means alone to refine the search results.

\section{Selection of studies}

Titles derived from this broad search were independently screened by 2 reviewers based on the inclusion criteria. The reviewers compared decisions and resolved differences through discussion, consulting a third party when consensus could not be reached. The third party was an experienced senior reviewer. Full reports were obtained for all the studies deemed eligible for inclusion in this paper. At the title and abstract stage, one reviewer accepted the citations that appeared to meet the inclusion criteria and sent them on for full-text review, with a second reviewer assessing only those citations the first reviewer deemed ineligible.

\section{Population}

Subjects in the included studies must have had at least one osseointegrated rough-surface, solid screw-type implant that presented with signs of peri-implantitis. All definitions of peri-implantitis were included.

\section{Inclusion and exclusion criteria}

The applied inclusion criteria were as follows:

- Systematic reviews, articles, proposing guidelines for peri-implantitis diagnosis (implant success and/or failure were also considered);

- Suggesting diagnostic parameters including clinical and radiological;

- Proposing classification for peri-implantitis (implant success and/or failure were also considered) according to the clinical and/or radiological parameters;
- Letters, editorials, $\mathrm{PhD}$ theses, and abstracts, in vitro and animal studies were not included;

- Publications in other than English language were not included.

\section{Sequential search strategy}

Following the initial literature search, all article titles were screened to eliminate irrelevant publications, case reports, and in vitro and animal studies. Next, studies were excluded based on data obtained from screening the abstracts. The final stage of screening involved reading the full texts to confirm each study's eligibility based on the inclusion and exclusion criteria.

\section{Data extraction}

The data were independently extracted from studies in the form of variables, according to the aims and themes of the present review, as listed as follows.

\section{Data items}

Data were collected from the included articles and arranged in the following fields:

- "Year" - revealed the year of publication;

- "Baseline records" - revealed the suggestions of the author if the baseline records (clinical and/or radiological) are needed;

- "Clinical parameters" - revealed what clinical parameters author suggests to use for periimplantitis diagnosis (including pain, PD, BOP, suppuration (SUPP)/exudate, mobility, other clinical parameters);

- "Radiographic evaluation" - described the suggested radiological method to diagnose periimplantitis/bone level changes around the dental implant;

- "Peri-implantitis/implant success/failure" described the definition used by the authors to describe peri-implantitis and/or implant failure/ success.

\section{Assessment of methodological quality}

The quality of all included studies was assessed during the data extraction process. The quality appraisal involved evaluating the methodological elements that might influence the outcomes of each study. The Cochrane Collaboration's 2-part tool for assessing risk of bias (Higgins and Green [14]) was used to assess bias across the studies and identify papers with intrinsic methodological and design flaws. 


\section{RESULTS}

\section{Search results}

Article review and data extraction were performed according to the PRISMA flow diagram (Figure 1). The initial search displayed 586 results from the MEDLINE (NCBI Ovid and PMC) database and one result from other sources. A total of 587 search results were screened. Preliminary exclusion was made by duplication, relevancy and case reports $(\mathrm{n}=561)$. A total of 26 articles and abstracts were selected according to relevancy after the removal of duplicates and exclusion of case reports. Further exclusions were made due to the amount of information the results contained about the selected topic $(\mathrm{n}=13)$. The remaining 13 articles were examined. Another exclusion was made because author suggested definition for peri-implantitis, but not the diagnostic methods [15], author suggests methods on peri-implantitis diagnosis, but the papers are not based on clinical study and/or literature review $[16,17]$. Finally, 10 articles were included in the literature review (Figure 1).

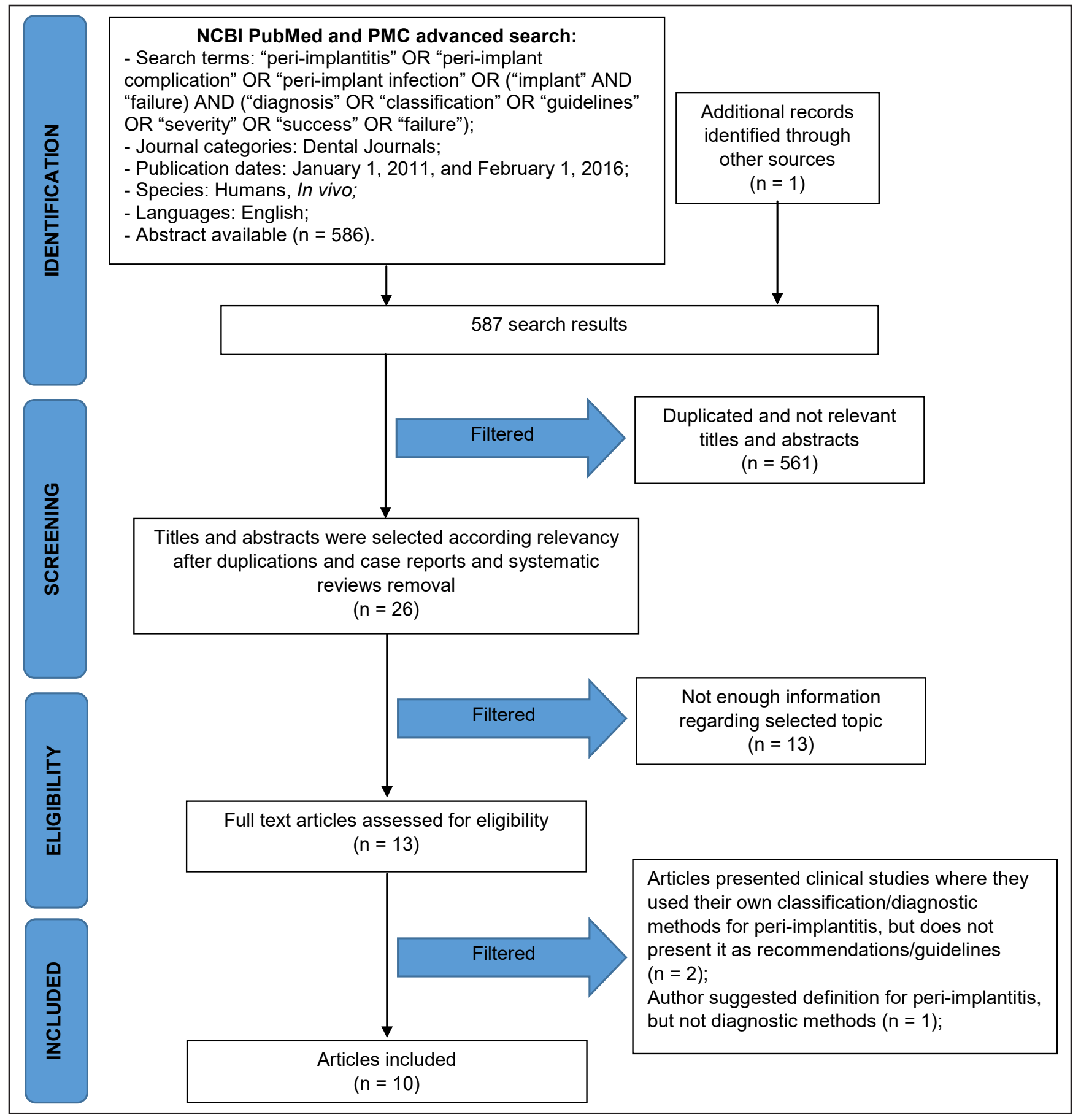

Figure 1. PRISMA flow diagram. 
Four of the included studies were papers from consensus conferences [18-20,23]; two of them suggested diagnostic guidelines $[\underline{24}, \underline{25}]$, three authors suggested the classification of peri-implantitis $[\underline{3}, \underline{21}, \underline{26}]$, and another suggested the index of implant success (Table 1) [222].

\section{Risk of bias within studies}

Only one of the included papers was a clinical study [3] which appeared to be of unclear risk (of bias for 4 key domains) (Table 2).

\section{Definitions \\ Peri-implantitis}

The articles used different definitions of periimplantitis (Table 1). Padial-Molina et al. [25] defined peri-implantitis as cases presenting $\mathrm{PD}>6 \mathrm{~mm}$ with bone loss $\geq 2 \mathrm{~mm}$, detected radiographically [25].

Froum et al. [21] suggested classification of periimplantitis based on a comparison of bone loss, determined by the percent of bone loss related to the length of the implant. They classified the disease into early, moderate, and advanced types, having periimplant measurements of $\geq 4 \mathrm{~mm}, \geq 6 \mathrm{~mm}$, or $\geq 8$ $\mathrm{mm}$ and bone loss of $>20 \%, 25-50 \%$, and $>50 \%$, respectively.

A recent paper by Ata-Ali et al. [26] offered the classification of peri-implantitis based on the amount of bone loss (ABL) occurring beyond the biological bone remodelling together with signs of inflammation (BOP and/or SUPP).

The Sixth European Workshop on Periodontology (EWP) [19] defined peri-implantitis as the presence of supporting bone loss in addition to inflammation of the mucosa. The Seventh EWP [20] specified that the key feature of peri-implantitis comprises changes in bone crest level associated with bleeding upon probing. According to the latest definition of the American Academy of Periodontology and the Eight EWP [ $2 \underline{3}, 24]$, peri-implantitis is characterized as an inflammatory process around an implant, including both soft-tissue inflammation and progressive loss of supporting bone beyond biological bone remodelling. Baseline clinical and radiographical measurements are needed to diagnose the disease. In the absence of previous radiographic records, the Eight EWP suggested using a threshold vertical distance of 2 $\mathrm{mm}$ from the expected marginal bone level following remodelling post-implant placement, provided periimplant inflammation is evident [23].

Koldsland et al. [ $\underline{3}]$ defined peri-implantitis as detectible bone loss with inflammation and suggested different levels of peri-implantitis according to the $\mathrm{ABL}(\geq 2 \mathrm{~mm}$ and $\geq 3 \mathrm{~mm})$ and pocket $\mathrm{PD}(\geq 4 \mathrm{~mm}$ and $\geq 6 \mathrm{~mm}$ ).

\section{Success/failure}

Two articles $[18,22]$ described the success and failure of dental implants.

Misch et al. [18] (The International Congress of Oral Implantologists (ICOI) Pisa Consensus Conference) categorized dental implants into four groups: successful, satisfactory, compromised, and failed. Successful implants present no pain, no history of exudate, and no mobility or bone loss $(<2 \mathrm{~mm}$ detected radiographically). Satisfactory implants present radiographic bone loss of $2-4 \mathrm{~mm}$. Compromised implants correspond to slight to moderate periimplantitis. These implants may cause sensitivity, have PD $>7 \mathrm{~mm}$, may have exudate history, no mobility and bone loss $>4 \mathrm{~mm}$ or $<1 / 2$ the implant body. In cases of failure the implant presents pain, exudate, mobility, and bone loss $>1 / 2$ the length of the implant. Kadkhodazadeh et al. [22] presented the implant success index, a scoring system to evaluate the clinical outcomes of dental implants that includes the evaluation of soft-tissue level, PD, BOP, hard-tissue level, and radiographic bone loss detected via a longcone parallel periapical technique. According to these evaluations, implants may be classified into eight groups: clinically healthy, soft-tissue inflammation, deep soft-tissue pockets (PD $>4 \mathrm{~mm}$ ), initiation of hard-tissue breakdown, hard-tissue breakdown plus soft-tissue recession, notable hard-tissue breakdown, notable hard-tissue breakdown plus soft-tissue recession, severe bone loss, and clinical failure implants presenting with mobility (Table 1) [22] .

\section{Clinical parameters}

According to the included articles, the time of prosthesis placement should be chosen to establish baseline criteria at both clinical and radiographic levels. Recorded baseline data should be used as a reference from which the development of peri-implant disease can be recognized and followed in subsequent examinations $[\underline{18-21}, \underline{23-25}]$. The following parameters are suggested to be used for the diagnosis of periimplantitis:

\section{Pain}

Only one paper suggested using pain as a diagnostic parameter [18]. Pain should not be associated with the implant after healing. 
Table 1. Description of the included papers

\begin{tabular}{|c|c|c|c|c|c|c|c|c|c|c|}
\hline Author & \begin{tabular}{c|} 
Year of \\
publication
\end{tabular} & Baseline records & Pain & PD & $\begin{array}{l}\text { Clinical para } \\
\text { BOP } \\
\end{array}$ & $\begin{array}{l}\text { ameters } \\
\text { SUPP/exudate }\end{array}$ & \begin{tabular}{|l|} 
Mobility \\
\end{tabular} & \begin{tabular}{|l|} 
Other clinical indices \\
\end{tabular} & Radiographic evaluation & Peri-implantitis/implant success \\
\hline Koldsland et al. [3] & 2010 & & & \begin{tabular}{|l} 
Different levels of severity: \\
$\quad \begin{array}{c}4 \mathrm{~mm} ; \\
\geq 6 \mathrm{~mm}\end{array}$
\end{tabular} & + & + & & & $\begin{array}{l}\text { Digital orthopantomograms and full-mouth } \\
\text { status intraoral analoue e ictures usedd; } \\
\text { different levels of peri-implantitis severity: } \\
\text { bone loss } \geq 2 \mathrm{~mm} \text {; and } \geq 3 \mathrm{~mm}\end{array}$ & $\begin{array}{l}\text { Peri-implantitis defined as detectible peri-implant bone loss with } \\
\text { inflammation. Levels of severity: } \\
\text { 1. bone loss } \geq 2 \mathrm{~mm}+\text { BOPOSUP at } P \mathrm{PD} \geq 4 \text { or } \geq 6 \mathrm{~mm} \text {; } \\
\text { 2. bone loss } \geq 3 \mathrm{~mm} \text { and BOP/SUPP at } P D \geq 4 \mathrm{~mm} \text { or PD } \geq 6 \mathrm{~mm} \text {. }\end{array}$ \\
\hline \multirow{5}{*}{$\begin{array}{l}\text { Misch et al. [18] } \\
\text { International } \\
\text { Congress of Oral } \\
\text { Implantologists } \\
\text { (COD) Pisa } \\
\text { Consensus } \\
\text { Conference }\end{array}$} & \multirow{5}{*}{2008} & $\begin{array}{c}\text { Bone-loss measurements should be } \\
\text { related to the original marginal bone level } \\
\text { at implant insertion. }\end{array}$ & + & 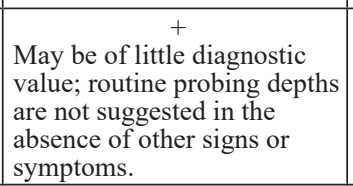 & & + & + & & $\begin{array}{l}\text { Conventional periapical radiographs; } \\
\text { computer-assisted images and customized } \\
\text { X-ray positioning devices may be superior. }\end{array}$ & $\begin{array}{l}\text { Success; } \\
\text { Satisfactory; } \\
\text { Compromised (peri-implantitis); } \\
\text { Compromised. }\end{array}$ \\
\hline & & Success & No pain & & & No history of exudate & \begin{tabular}{c|} 
No \\
mobility
\end{tabular} & & $<2 \mathrm{~mm}$ & \\
\hline & & Satisfactory & No pain & & & No history of exudate & \begin{tabular}{|c|} 
No \\
mobility
\end{tabular} & & 2 to $4 \mathrm{~mm}$ & \\
\hline & & \begin{tabular}{|c|c|}
$\begin{array}{c}\text { Compromised = slight to moderate peri- } \\
\text { implantitis }\end{array}$ \\
\end{tabular} & May be sensitive & $\mathrm{PD}>7$ & & May have exudate history & \begin{tabular}{|c|} 
No \\
mobility
\end{tabular} & & $>4 \mathrm{~mm},<1 / 2$ implant body & \\
\hline & & \begin{tabular}{|c|} 
Failure \\
\end{tabular} & Pain & & & Exudate & Mobility & & $>1 / 2$ length of implant & \\
\hline \begin{tabular}{c|} 
Lindhe and Meyle \\
{$[19]$} \\
Sixth European \\
Workshop on \\
Periodontology \\
\end{tabular} & 2008 & 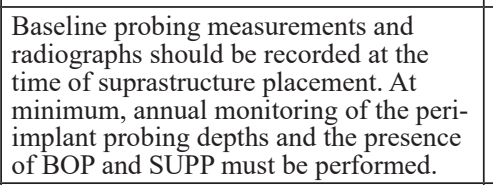 & & $\begin{array}{l}++ \\
\text { Probing at four surfaces is } \\
\text { essential for diagnosis of } \\
\text { peri-implantitis. }\end{array}$ & $\begin{array}{c}\text { BOP indicates } \\
\text { the presence of } \\
\text { inflammation in } \\
\text { the peri-implant } \\
\text { mucosa. }\end{array}$ & $\begin{array}{l}\quad++ \\
\text { Suppuration is a sign of } \\
\text { peri-implantitis. }\end{array}$ & + & & $\begin{array}{l}\text { When clinical signs suggest the presence of } \\
\text { peri-implantitis, the clinician is advised to } \\
\text { take a radiograph. }\end{array}$ & 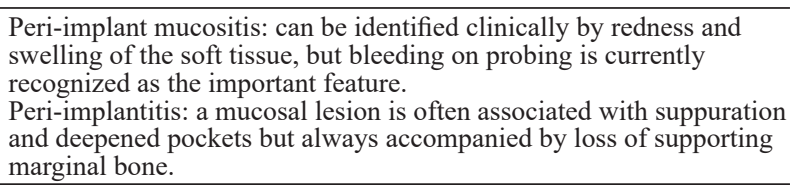 \\
\hline \begin{tabular}{c|} 
Lang and Berghlundh \\
{$[20]$} \\
Seventh European \\
Workshop on \\
Periodontology
\end{tabular} & 2011 & 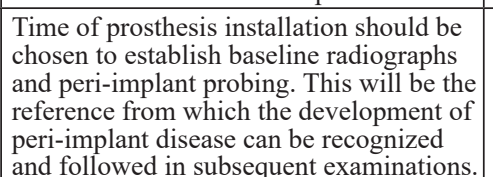 & & + & + & + & & & $\begin{array}{l}\text { When changes in clinical parameters indicate } \\
\text { disease (BOP, increased PD), the clinician is } \\
\text { encouraged to take a a radiograph to evaluate } \\
\text { possible bone loss (PD }>5 \text { mm }+ \text { BOP, take } \\
\text { a radiograph) }\end{array}$ & $\begin{array}{l}\text { Peri-implantitiss changes in the level of crestal bone, presence of } \\
\text { bleeding on probing and or suppuration; with or without concomitant } \\
\text { deepening of peri-implant pockets. Puss is a common finding at peri- } \\
\text { implantitis sites. }\end{array}$ \\
\hline \multirow{4}{*}{ Froum et al. [21] } & \multirow{4}{*}{2012} & \begin{tabular}{|l|}
$\begin{array}{l}\text { Obtain a periapical radiograph } \\
\text { immediately following placement of the } \\
\text { definite prosthesis. }\end{array}$ \\
\end{tabular} & & + & + & + & & & + & $\begin{array}{l}\text { Early peri-implantitiss; } \\
\text { Moderate peri-implantitis; } \\
\text { Advanced peri-implantitis. }\end{array}$ \\
\hline & & Early peri-implantitis & & $\mathrm{PD} \geq 4 \mathrm{~mm}$ & BOP & $\begin{array}{c}\text { +/- SUPP noted on two or } \\
\text { more aspects of the implant }\end{array}$ & & & $<25 \%$ of the implant length & \\
\hline & & Moderate & & $\mathrm{PD} \geq 6 \mathrm{~mm}$ & ВОР & $\begin{array}{c}+/ \text { - SUPP noted on two or } \\
\text { more aspects of the implant }\end{array}$ & & & $25-50 \%$ of the implant length & \\
\hline & & Advanced & & $\mathrm{PD} \geq 8 \mathrm{~mm}$ & BOP & \begin{tabular}{|c|} 
+/- SUPP noted on two or \\
more aspects of the implant
\end{tabular} & & & $>50 \%$ of the implant length & \\
\hline $\begin{array}{c}\text { Kadkhodazadeh et } \\
\text { al. [22] }\end{array}$ & 2012 & Implant success index & Not reported & $\begin{array}{l}\quad++ \\
\mathrm{PD} \leq 4 \mathrm{~mm} ; \\
\mathrm{PD}>4 \mathrm{~mm}\end{array}$ & + & $\begin{array}{l}\text { Is neither representative of } \\
\text { a specific condition nor a } \\
\text { predictable factor for further } \\
\text { tissue breakdown }\end{array}$ & + & & $\begin{array}{l}\text { Long cone, parallel peri-apical technique; } \\
\leq 2 \mathrm{~mm}(\leq 20 \%) \text { - inititition of hard-tissue } \\
\text { breakdown } \\
2 \text { to } 4 \mathrm{~mm}(<40 \%) \text { - hard-tissue breakdown } \\
>40 \% \text { - severe bone loss }\end{array}$ & 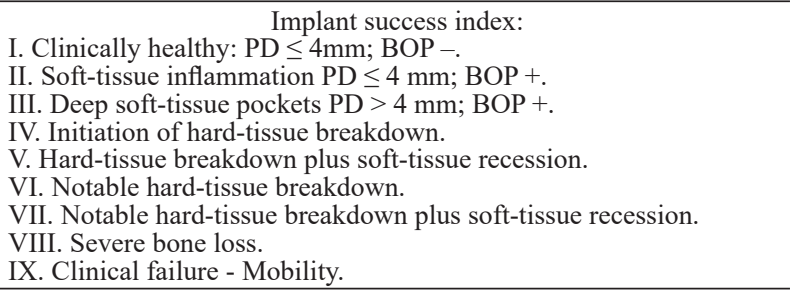 \\
\hline $\begin{array}{l}\text { Sanz et al. [23] } \\
\text { Eight European } \\
\text { Workshop on } \\
\text { Periodontology }\end{array}$ & 2012 & $\begin{array}{l}\text { Baseline clinical and radiological } \\
\text { data should be established once the } \\
\text { remodelling phas post-implant } \\
\text { placement has occurred. }\end{array}$ & & & & & & & $\begin{array}{l}\text { Long-cone parallel radiographss in the } \\
\text { absence of previous radiographic records, } \\
\text { a threshold vertical distanco of } 2 \text { mm from } \\
\text { the expected martinal bone level following } \\
\text { remodelling post-implant placementi is } \\
\text { recommended, provided peri-implant } \\
\text { inflammation is evident. }\end{array}$ & $\begin{array}{l}\text { Peri-implantitis - inflammatory process around the implant that } \\
\text { includes both soft-tissue inflam mation and progressive bone loss of } \\
\text { supporting bone beyond biological bone remodelling. }\end{array}$ \\
\hline $\begin{array}{c}\text { American Academy } \\
\text { of Periodontology } \\
{[24]}\end{array}$ & 2013 & \begin{tabular}{|l|}
$\begin{array}{l}\text { Establish clinical and radiographic } \\
\text { baseline at final prosthesis insertion. } \\
\text { There is no single diagnostic tool that } \\
\text { can, with certaninty, establish a diagnosis } \\
\text { of peri-implantitis. }\end{array}$ \\
\end{tabular} & & + & + & + & + & $\begin{array}{l}\text { Bacterial culturing, } \\
\text { inflammatory markers, } \\
\text { and genetics may be } \\
\text { useful in the diagnosis. }\end{array}$ & $\begin{array}{l}\text { Periapical radiographs should be } \\
\text { perpendiciular to the implant body. } \\
\text { CBCT may be cosiderd depending on the } \\
\text { location of progressive attachment loss. }\end{array}$ & Used the definition by Sanz et al. [23] \\
\hline$\underset{[25]}{\text { Padial- Molina et al. }}$ & 2014 & $\begin{array}{l}\text { Baseline records should be used as a } \\
\text { reference from which the development of } \\
\text { peri-implant disease can be recognized } \\
\text { and followed din subsequentexexaminations. }\end{array}$ & & $\begin{array}{l}\text { + } \\
\begin{array}{l}\text { Should be repeated over } \\
\text { time but not considered } \\
\text { an absolute and isolated } \\
\text { diagnostic tool. }\end{array}\end{array}$ & + & + & + & & $\begin{array}{l}\text { Conventional radiographs: intraoral and } \\
\text { panoramic are reliable; computer assisted are } \\
\text { more accurate. } \\
\text { Take a radiograph if } \mathrm{PD}<5 \mathrm{~mm}+\mathrm{BOP} / \\
\text { SUPP detected. }\end{array}$ & $\begin{array}{l}\mathrm{PD} \leq 5 \mathrm{~mm}+\mathrm{BOP} / \mathrm{SUPP} /+ \text { bone loss } \leq 2 \mathrm{~mm}=\text { mucositis. } \\
\mathrm{PD}>6 \mathrm{~mm}+\text { bone loss } \geq 2 \mathrm{~mm}=\text { peri-implantitis. }\end{array}$ \\
\hline Ata-Ali et al. [26] & 2015 & $\begin{array}{l}\text { X-rays must be obtained at implant } \\
\text { placement and prosthesis intallation to } \\
\text { allow comparisons with the periapical } \\
\text { X-rays obtained at periodic patient } \\
\text { controls. }\end{array}$ & $\begin{array}{l}\text { Peri-implant } \\
\text { probing is essential } \\
\text { for establishing al } \\
\text { diagnosis of peri- } \\
\text { implant disease. }\end{array}$ & & + & + & & & $\begin{array}{l}\text { Parallelized intraaral X-rays should be used } \\
\text { in all dental implants to determine possible } \\
\text { marginal bone loss. }\end{array}$ & 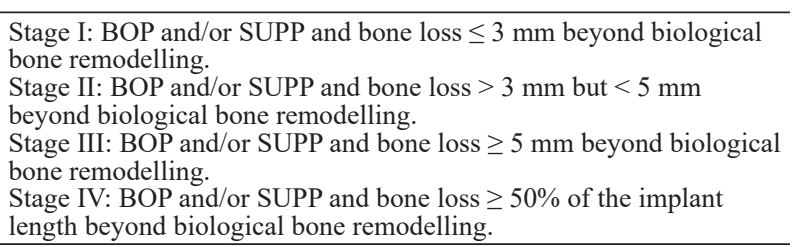 \\
\hline
\end{tabular}

+ parameter suggested to be used; $\mathrm{BOP}$ = bleeding on probing; $\mathrm{PD}$ = probing-pocket depth; $\mathrm{SUPP}$ = suppuration. 
Table 2. Assessment of the risk of bias

\begin{tabular}{c|c|c|c|c|c|c|c}
\hline Author & $\begin{array}{c}\text { Year of } \\
\text { publication }\end{array}$ & $\begin{array}{c}\text { Random sequence } \\
\text { generation }\end{array}$ & $\begin{array}{c}\text { Allocation } \\
\text { concealment }\end{array}$ & Blinding & $\begin{array}{c}\text { Incomplete } \\
\text { outcome data }\end{array}$ & $\begin{array}{c}\text { Selective } \\
\text { reporting }\end{array}$ & $\begin{array}{c}\text { Other } \\
\text { bias }\end{array}$ \\
\hline Koldsland et al $[3]$ & 2010 & $?$ & $?$ & $?$ & + & $?$ & + \\
\hline
\end{tabular}

$+=$ low risk; $?=$ unclear risk; $-=$ high risk.

Percussion and forces up to $500 \mathrm{~g}$ may be used clinically to evaluate implant pain or discomfort. Usually, pain from the implant body does not occur unless the implant is mobile and surrounded by inflamed tissues or has rigid fixation but impinges on a nerve. Pain during function places the implant in the failure category [18].

\section{Mobility}

Five articles suggested evaluating implant mobility $[\underline{18}, \underline{19}, \underline{22}, \underline{24}, \underline{25}]$. All authors agreed that implant mobility indicates the final stage of peri-implant disease, characterized by complete loss of the direct bone-to-implant interface $[\underline{18}, \underline{19}, \underline{22}, \underline{24}, \underline{25}]$.

\section{Probing}

Probing around implants should be repeated over time $[21,22,24,25]$.

The specified PD varies between $\geq 4 \mathrm{~mm}$ and $>5 \mathrm{~mm}$. According to different authors, different thresholds are referred to as peri-implantitis: $>6 \mathrm{~mm}$ PD [25]; $\geq 4 \mathrm{~mm}$ initial peri-implantitis, $\geq 6 \mathrm{~mm}$ moderate periimplantitis, and $\geq 8 \mathrm{~mm}$ severe peri-implantitis [21]; $<4 \mathrm{~mm}$ pockets indicate soft-tissue inflammation and $>4 \mathrm{~mm}$ soft-tissue pockets [22] .

Koldsland et al. []ㅡ used two PDs, $\geq 4 \mathrm{~mm}$ and $\geq 6$ $\mathrm{mm}$, accordingly, to distinguish different levels of peri-implantitis severity. The paper by Ata-Ali et al. [26] stated that peri-implant probing is essential for establishing a diagnosis of peri-implant disease. However, this parameter is not included in the proposed classification of peri-implantitis suggested by the authors.

In contrast, according to Misch et al. [1] $]$, probing around the implants may be of little diagnostic value, and routine probing is not recommended. Probing as a diagnostic parameter is recommended in the compromised implant group (which corresponds slightly to moderate peri-implantitis).

According to the Seventh European Workshop of Periodontics [20] and Padial-Molina et al. [25], when changes in clinical parameters indicate disease (increased values in BOP, increased PD [ $>5 \mathrm{~mm}]$ ), the clinician is encouraged to take a radiograph to evaluate possible bone loss [20,25].

\section{Bone loss}

Conventional periapical radiographs are recommended [18,21-25]. Panoramic radiographs (PRs) might also be used for peri-implantitis diagnosis [25]. However, three-dimensional radiographs, whereby not only mesial and distal but also buccal and lingual/palatinal bone walls could be evaluated, are superior $[\underline{18}, \underline{24}, \underline{25}]$.

Bone-loss thresholds to diagnose peri-implantitis suggested by the authors differ: Padial-Molina et al. [25] suggested that bone loss $>2 \mathrm{~mm}$ indicated periimplantitis, while Misch et al. [18] suggested the threshold of $>4 \mathrm{~mm}$. The implant success index by Kadhazahed et al. [22] reported that $\leq 2 \mathrm{~mm}(\leq 20 \%)$ of bone loss indicated the initiation of hard-tissue breakdown, 2 - $4 \mathrm{~mm}(<40 \%)$ indicated hard-tissue breakdown, and $>40 \%$ indicated severe bone loss. Ata-Ali et al. [26] suggested using different stages of peri-implantitis based on the amount of marginal bone loss beyond biological bone remodelling (Stage $\mathrm{I}: \leq 3$ mm; Stage II: $>3 \mathrm{~mm}$ but $<5 \mathrm{~mm}$; Stage III $: \geq 5 \mathrm{~mm}$; Stage IV: $\geq 50 \%$ of the implant length).

Peri-implantitis classification by Froum et al. [21] is based on a comparison of bone loss determined by changes in the percentage of bone loss related to the length of the implant: bone loss of $<25 \%$ of the implant length indicates early peri-implantitis, 25 - 50\% of the implant length indicates moderate periimplantitis, and $>50 \%$ of the implant length indicates severe peri-implantitis. Koldsland et al. [3] classified peri-implantitis into different levels of severity according to the bone loss: $\geq 2 \mathrm{~mm}$ and $\geq 3 \mathrm{~mm}$, accordingly.

The Sixth, Seventh and Eight EWPs [19,20,23] suggested a diagnosis of peri-implantitis when changes in the level of crestal bone occur compared to baseline data. In the absence of previous radiographic records, a threshold vertical distance of $2 \mathrm{~mm}$ from the expected marginal bone level following remodeling post-implant placement is recommended provided peri-implant inflammation is evident [23].

\section{Other clinical parameters}

The paper by the American Academy of Periodontology suggested that bacterial culturing, 
inflammatory markers, and genetics may be useful in the diagnosis of peri-implantitis [24].

\section{Rationale for diagnosis and prognosis of peri- implantitis}

We suggest that the clinician start the diagnostic procedure with the following questions (Figure 2):

\section{Step I. Is there implant mobility?}

This might be due to the abutment loosening. If so, then the occlusion should be checked and adjusted. However, if it is due to a lack of osseointegration, the implant has failed and has to be removed.

\section{Step II. Is there BOP/SUPP/increased peri-implant PD?}

Probing is an essential diagnostic tool. Probe periimplant tissues at $4-6$ sites and evaluate PD, BOP, and SUPP. BOP suggests inflammation of the soft tissues; SUPP Is usually associated with periimplantitis.

If there is no baseline measurement, $\mathrm{PD}>5 \mathrm{~mm}$ together with BOP around the implant at more than one site should encourage the clinician to take a radiograph.

If there are baseline measurements, then increased PD with BOP and/or suppuration indicates the need to evaluate bone level around the implant.

If the probe penetrates $>5 \mathrm{~mm}$ around the implants at just one site with no soft-tissue inflammation (no BOP/SUPP), it might be due to bone dehiscence. In this case, it is not due to peri-implant disease.

Prosthetic construction may hinder the probing; if possible, remove the prosthetic construction.

\section{Step III. Is there bone loss?}

Standardized periapical radiography is indicated for peri-implantitis diagnostics. It should be parallel to the implant body. With periapical radiography bone levels mesial and distal to the implant can be evaluated. Three-dimensional imaging, like cone beam computed tomography (CBCT), might be more informative because it enables the evaluation of vestibular and oral bone plates of implants in the vertical as well as the horizontal dimensions [27]. However, in terms of what concerns the mesial and distal bone levels, a clinical study [27] demonstrated that measurements are equally accurate for CBCT

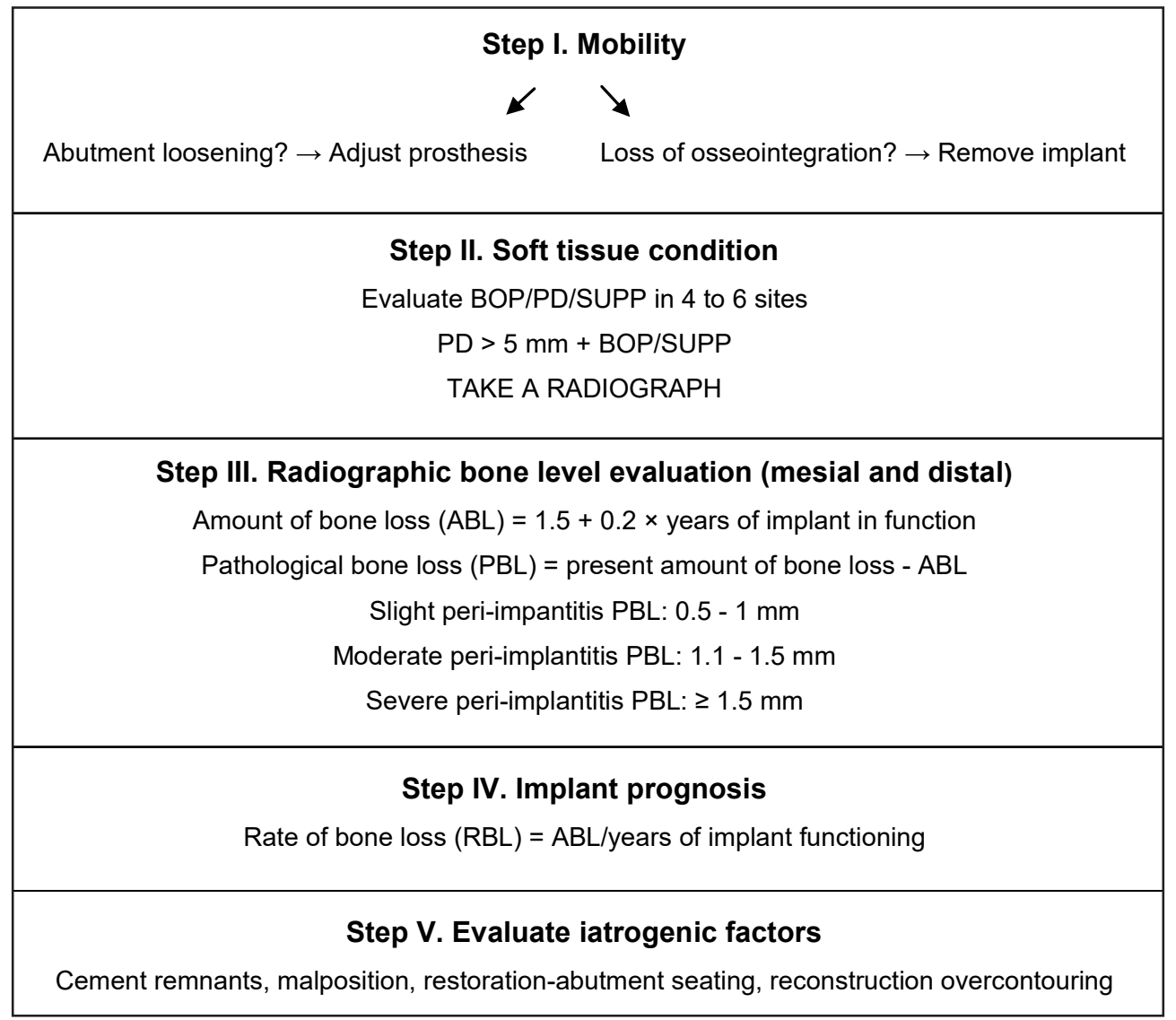

Figure 2. Rationale for diagnosis and prognosis of peri-implantitis. BOP = bleeding on probing; PD = probing-pocket depth; SUPP $=$ suppuration; BL implant $=$ bone level implant; SLT implant $=$ soft tissue level implant. 
and standard intraoral radiography (IR). In agreement with this study and previously reviewed papers, we suggest that periapical radiographs are enough to diagnose peri-implantitis. If bone levels differ in mesial and distal aspects, then the more-pronounced aspect should be used for the evaluation. As a reference point, fixture-abutment connection or abutment-crown connection should be used for bonelevel implants and implant shoulder for soft-tissuelevel implants.

The consensus report from the First EWP suggested that "the criteria of success demand an average marginal bone loss of less than $1.5 \mathrm{~mm}$ during the first year after the insertion of the prosthesis and thereafter less than $0.2 \mathrm{~mm}$ annual bone loss" [28]. Using the abovementioned success criteria and, in addition, evaluating the time of implant in function, the maximal physiological ABL could be calculated by using the following formula: $1.5 \mathrm{~mm}+$ $0.2 \mathrm{~mm} \times$ years of implant in function. Pathological (supraphysiological) bone loss (PBL) could be calculated by subtracting the maximum physiological bone loss from the present amount of bone loss detected radiographically. Depending on the result, peri-implantitis could be classified as slight (if PBL is $0.5-1 \mathrm{~mm}$ ), moderate (if PBL is $1.1-1.5 \mathrm{~mm}$ ), or severe (if PBL is $\geq 1.5 \mathrm{~mm}$ ).

\section{Step IV. Implant prognosis}

Implant functioning prognosis depends on the amount and the rate of bone loss (RBL). RBL could be evaluated by dividing the ABL by the years of implant functioning. According to the bone loss related to implant length, we can discover how much bone loss could be expected yearly. Therefore, we can predict when the amount of more than half of an implant body could be expected. However, if the patient was not under regular follow-up, it might be hard to evaluate the progress of bone loss and predict possible bone loss in the future.

As suggested by other authors [29], we do agree that in cases in which bone loss extends more than half of the fixture length, it is more rational to remove the implant than to treat it.

\section{Step V. Evaluate iatrogenic factors that caused the disease}

Iatrogenic factors such as cement remnants, malpositioning of the implant, inadequate restorationabutment seating, and overcontouring of the reconstruction that disturbs proper plaque control should be evaluated.

\section{DISCUSSION}

Peri-implantitis is defined as an inflammatory process affecting the tissues around an osseointegrated implant in function, resulting in loss of supporting bone [28]. An advanced peri-implant lesion is easily diagnosed on a radiograph by detecting the bone loss around the implant. However, in advanced cases the prognosis of the dental implant is usually doubtful, and removal is often a better option [29]. Peri-implant disease should be diagnosed as early as possible to allow intervention before a substantial portion of the supporting bone is lost. Therefore, diagnostic procedures used around implants should include sensitive parameters to detect early signs and symptoms of infection.

The present investigation aimed to review the current literature on the clinical methods and parameters suggested for use for peri-implantitis diagnosis. An electronic search of MEDLINE (Ovid) and EMBASE databases was performed including studies published in the English language between January 1, 2011, and February 1, 2016. Additionally, a hand search was carried out in dental-implants-related journals.

Ten articles were included [3,18-26], and 4 of them were consensus papers $[18-20,23]$. Eight of them defined peri-implantitis diagnosis [3, 19-21, 23-26], and 2 of them defined the diagnosis of successful and failed implants [18, $\underline{22}]$. All articles suggested combining clinical and radiological data to diagnose peri-implantitis and/or to determine implant success (or failure) [ㄹ, 18-26]. Soft-tissue inflammation (diagnosed as BOP), SUPP, and increased periimplant pockets over time, in combination with marginal bone loss, were defined as the key factors for diagnosis. However, it must be noted that except for the three papers of the EWP $[19,20,23]$, the rest of the papers' different definitions were used (Table 2). Included studies used different thresholds for bone-loss evaluation and different thresholds for periimplant pocketing. This leads to the conclusion that currently there is no single uniform definition of periimplantitis or the parameters (threshold of parameters) that should be used in its diagnosis.

In agreement with the present review, we would suggest using the following parameters for periimplantitis diagnosis: BOP, SUPP, mobility, periimplant probing, and radiographical bone-level evaluation.

The presence of BOP is a sign of soft-tissue inflammation and is considered a valuable parameter for diagnosing peri-implant disease. An experimental study [30] showed that healthy peri-implant sites lacked BOP, while there was increased BOP 
at mucositis (67\%) and peri-implantitis (91\%) sites. Bleeding following probing peri-implant tissues has a high predictive value for disease progression, while the absence of BOP is a reliable predictor of stable and healthy peri-implant conditions $[\underline{31}, \underline{32}]$.

The presence of SUPP is the result of infection and an inflammatory lesion, which indicates the presence of an infection and is a common finding in periimplantitis sites [20]. We suggest evaluating BOP and SUPP while probing peri-implant tissues because these parameters may reveal the problem, but they cannot be used on their own as diagnostic parameters. Periodontal probing using light pressure $(0.25 \mathrm{Ncm})$ does not damage the mucosal seal and is considered an important and reliable tool for diagnosing and monitoring the presence of peri-implant health or disease $[\underline{30}, \underline{33}, \underline{34}]$. In healthy peri-implant conditions, experimental studies have indicated that when a light probing force was used $(0.2-0.3 \mathrm{~N})$, the tip of the probe stopped coronally to the bone level, at the apical extension of the barrier epithelium. However, in sites with peri-implant disease, the probe tip penetrated to a position closer to the alveolar bone crest $[\underline{30}, \underline{33}]$. This reflected an increase in the probe penetration as the degree of inflammation around implants increased [34].

Clinical studies have indicated that PDs were deeper for implants presenting with radiographic bone loss compared to implants with no bone loss [35]. Thus, it is evident that probing may be useful in identifying implants with bone loss.

However, whether different pocket-PDs should be used for tissue-level and bone-level implants is a question of debate. A systematic review by Vouros et al. [36] investigated possible differences in clinical outcomes between tissue-level and bonelevel implants after 1 year of functioning and found no significant differences in clinical parameters, including PD and bone loss (no statistically significant differences were reported). Also, the literature has shown that PDs adjacent to laser-microtextured collar implants were significantly lower than those observed adjacent to machined collar implants [38].

We suggest that the threshold for PD should be > $5 \mathrm{~mm}$ in these cases there the bone loss could be expected, which indicates a need to evaluate marginal bone radiographically.

The radiographic image is the most important source of information for determining the amount of cervical alveolar bone loss around dental implants [37]. Bone loss is the most important parameter that differentiates peri-implant mucositis from peri-implantitis. Marginal bone loss occurs following dental implant placement [39]. Such initial marginal bone loss progresses to the first implant thread or to the first contact of the bone with a rough surface, slightly coronal to the first thread $[\underline{39}, \underline{40}]$. The observed bone loss following the first year of implant functioning has the highest rate and is thought to be related to the establishment of the biological width around the implant and biomechanical adaptation of the bone to occlusal loading [41].

In addition, other factors, such as the implant neck length, design and surface characteristics, implantabutment connection, addition of microthreads, soft-tissue vertical thickness, implant diameter and insertion depth, and concept of platform switching, may have an influence on the marginal bone loss around dental implants $[\underline{39}, \underline{42-47}]$.

The transmucosal location of the microgap in tissuelevel implants seems to be advantageous because it is positioned at a distance from the bone crest and has lesser marginal bone reactions compared to crestally placed implants [42]. However, long-term radiographic studies of tissue-level dental implants have also demonstrated peri-implant bone loss ranging from 0.6 to $1 \mathrm{~mm}$ during the first year of functioning and $<0.2 \mathrm{~mm}$ per year thereafter [42].

The previously mentioned systematic review by Vouros et al. [36] investigated possible differences in clinical outcomes between tissue-level and bonelevel implants after 1 year of functioning. No significant differences in bone loss were detected. Contradictorily, the clinical retrospective cohort study that aimed to compare the amount of marginal bone loss in bone- level and soft-tissue-level implant systems found no statistically significant difference between the two groups at time periods of $6-12$ months, but in later time periods there was a slightly greater amount of marginal bone loss around tissuelevel implants compared to bone-level implants [48].

The question of whether different bone-loss thresholds should be used for different implant types should also be discussed. We would suggest using the definition suggested by the First European Workshop on Periodontology and evaluating the implant functioning time [28]. This is a simple and reliable way to diagnose peri-implantitis. We suggested using the categorization of $\mathrm{ABL}$, which is calculated using the definition of the First EWP and includes the time of implant in function [28]. If bone loss extends then it is peri-implantitis.

We suggest peri-implantitis classification based on the amount of pathological bone loss, which is calculated by subtracting the maximal physiological bone loss from the present $\mathrm{ABL}$.

The RBL should also be evaluated. This is the parameter that determines the prognosis of 
the implant. RBL could be calculated by dividing ABL from the years of implant functioning. This is how we can predict how much bone resorption could be expected every year. However, bone resorption might be influenced by a variety of local and/or systemic factors and therefore hardly predictable; thus, our suggested RBL might not be a useful parameter in every peri-implantitis case.

Radiographs should be obtained once tissue homeostasis has been established (upon the completion of the prosthodontic work). We suggest clinicians take periapical radiographs that are parallel to the implant body and evaluate bone levels mesial and distal to the implant. An interesting fact was discovered in the literature: There was significantly more bone loss on the mesial surface than on the distal surface [49]. A study by Norton [ $\underline{50}$ ] observed a similar trend, with greater bone loss on the distal surfaces. Variations in oral hygiene techniques and bone quality among patients may play a role in boneloss patterns.

A recent study by Kühl et al. [51] evaluated twoand three-dimensional radiographic techniques to determine peri-implantitis-related bone loss around dental implants. The authors compared the performance of detecting different peri-implant bone defects in IR, PR, CBCT, and computed tomography (CT). According to the study, IR should still be recommended as a favourable method for evaluating bone loss around dental implants, while CT demonstrated the lowest performance in detecting peri-implant bone defects [51].

The study by Ritter et al. [27] assessed the accuracy of three-dimensional CBCT and IR in visualizing peri-implant bone compared with histology. The study found that IR and CBCT performed similarly in assessing medial and distal bone level, but, within its limits, the CBCT can assess oral and buccal bone. When information about osseous perforation of implants is needed, CBCT may still provide clinically valuable information [27].

A recent study by Garcia-Garcia et al. [52] aimed to assess the accuracy of periapical radiographs in measuring peri-implant bone levels compared to the bone level assessed intraoperatively. The authors found that intraoperatively measured interproximal bone levels were statistically significantly more apical than the bone levels obtained from the periapical radiographs and highlights the fact that bone level cannot be predicted exactly from radiographs. Therefore, the bone loss associated with periimplantitis could be higher than observed in the preoperative radiographs, the prognosis of the implant might be worse than expected, and a slight degree of bone loss might remain undetected in periapical radiographs, making it hard to diagnose periimplantitis at its early stages.

It has to be realized that peri-implantitis may be initiated and/or maintained by iatrogenic factors, such as excess cement remnants, inadequate restorationabutment seating, implant malpositioning, and technical complications.

An example of iatrogenic peri-implant infection is peri-implantitis due to submucosal persistence of luting cement, in which the presence of a foreign body gives rise to a bacterial infection. Wilson [53] stated that excess cement was associated with clinical and/ or radiographic signs of peri-implant disease in $81 \%$ of 39 cases. Once the excess cement was removed, the clinical signs of disease disappeared in $74 \%$ of cases. The differential diagnosis of peri-implantitis should therefore include the search for a specific underlying cause, even if SUPP, or the presence of biofilm, points to a bacterial infection.

Although loss of bone is one of the key diseasedefining signs for peri-implantitis diagnosis, this cannot be the only feature. Bone resorption can be caused by the deep insertion of an implant or the placement of implants too close to each other $[54,55]$. Moreover, not every PD $>5 \mathrm{~mm}$ around implants is a definite sign of peri-implantitis. The type and shape of the implant, the connection parts, and the prosthetic suprastructure affect the dimensions of the peri-implant tissues. Soft-tissue conditioning in the aesthetic zone to create the illusion of an interdental papilla can lead to an increase in the distance from the implant shoulder to the mucosal margin up to $5 \mathrm{~mm}$ [56].

Taking into account the present review's results and our own clinical experience, we suggest the following diagnostic scheme for peri-implantitis: evaluate softtissue inflammation, $\mathrm{ABL}$, and $\mathrm{RBL}$ to make the prognosis of the implant according to the RBL.

\section{Limitations}

This paper was based on literature reviews and authors' experience suggesting peri-implantitis diagnostic and prognostic indexes. Only one clinical study was included [3] . However, it appeared to be of unclear risk [3] . According to the Cochrane Collaboration's tool for assessing risk of bias, the proportion of information from studies with unclear or high risk of bias is sufficient to affect the interpretation of results [14]. The current review used two databases and only included studies written in English, which could introduce a publication bias. 


\section{CONCLUSIONS}

The present systematic review revealed that at present a uniform classification and diagnostic methodology for peri-implantitis is lacking. All of the included papers reported that clinical and radiographical data should be used for peri-implantitis diagnosis. However, in the majority of them different definitions of peri-implantitis or implant success as well as different thresholds for clinical and radiographical parameters were used. Therefore, based on current evidence, rationale for diagnosis and prognosis of peri-implantitis are suggested. They are based on a consecutive evaluation of soft-tissue conditions and the amount of bone loss, upon which classification of peri-implantitis and prognosis of the implant affected by peri-implant disease is suggested.

\section{ACKNOWLEDGMENTS AND DISCLOSURE STATEMENTS}

The authors report no conflicts of interest related to this study.

\section{REFERNCES}

1. Lang NP, Berglundh T, Heitz-Mayfield LJ, Pjetursson BE, Salvi GE, Sanz M. Consensus statements and recommended clinical procedures regarding implant survival and complications. Int J Oral Maxillofac Implants. 2004;19 Suppl:150-4. [Medline: 15635955]

2. Pjetursson BE, Tan K, Lang NP, Brägger U, Egger M, Zwahlen M. A systematic review of the survival and complication rates of fixed partial dentures (FPDs) after an observation period of at least 5 years. Clin Oral Implants Res. 2004 Dec;15(6):667-76. Review. [Medline: 15533127]

3. Koldsland OC, Scheie AA, Aass AM. Prevalence of peri-implantitis related to severity of the disease with different degrees of bone loss. J Periodontol. 2010 Feb;81(2):231-8. [Medline: 20151801] [doi: 10.1902/jop.2009.090269]

4. Berglundh T, Persson L, Klinge B. A systematic review of the incidence of biological and technical complications in implant dentistry reported in prospective longitudinal studies of at least 5 years. J Clin Periodontol. 2002;29 Suppl 3: 197-212; discussion 232-3. [Medline: 12787220] [doi: 10.1034/j.1600-051X.29.s3.12.x]

5. Mombelli A, Müller N, Cionca N. The epidemiology of peri-implantitis. Clin Oral Implants Res. 2012 Oct;23 Suppl 6: 67-76. [Medline: 23062130] [doi: 10.1111/j.1600-0501.2012.02541.x]

6. Mombelli A, van Oosten MA, Schurch E Jr, Land NP. The microbiota associated with successful or failing osseointegrated titanium implants. Oral Microbiol Immunol. 1987 Dec;2(4):145-51. [Medline: 3507627] [doi: 10.1111/j.1399-302X.1987.tb00298.x ]

7. Jepsen S, Berglundh T, Genco R, Aass AM, Demirel K, Derks J, Figuero E, Giovannoli JL, Goldstein M, Lambert F, Ortiz-Vigon A, Polyzois I, Salvi GE, Schwarz F, Serino G, Tomasi C, Zitzmann NU. Primary prevention of periimplantitis: managing peri-implant mucositis. J Clin Periodontol. 2015 Apr;42 Suppl 16:S152-7. [Medline: 25626479] [doi: $10.1111 /$ jepe. 12369]

8. Albrektsson T, Buser D, Sennerby L. Crestal bone loss and oral implants. Clin Implant Dent Relat Res. 2012 Dec;14(6): 783-91. [Medline: 23199435] [doi: 10.1111/cid.12013]

9. Konstantinidis IK, Kotsakis GA, Gerdes S, Walter MH. Cross-sectional study on the prevalence and risk indicators of peri-implant diseases. Eur J Oral Implantol. 2015 Spring;8(1):75-88. [Medline: 25738181]

10. Qian J, Wennerberg A, Albrektsson T. Reasons for marginal bone loss around oral implants. Clin Implant Dent Relat Res. 2012 Dec;14(6):792-807. [Medline: 23198697] [doi: 10.1111/cid.12014]

11. Atieh MA, Alsabeeha NH, Faggion CM Jr, Duncan WJ. The frequency of peri-implant diseases: a systematic review and meta-analysis. J Periodontol. 2013 Nov;84(11):1586-98. [Medline: 23237585] [doi: 10.1902/jop.2012.120592]

12. Mombelli A, Müller N, Cionca N. The epidemiology of peri-implantitis. Clin Oral Implants Res. 2012 Oct;23 Suppl 6: 67-76. [Medline: 23062130] [doi: 10.1111/j.1600-0501.2012.02541.x]

13. Moher D, Liberati A, Tetzlaff J, Altman DG; PRISMA Group. Preferred reporting items for systematic reviews and meta-analyses: the PRISMA statement. Int J Surg. 2010;8(5):336-41. [Medline: 20171303] [doi: 10.1016/j.ijsu.2010.02.007]

14. Higgins JPT, Green S. Cochrane Handbook for Systematic Reviews of Interventions. [URL: http://www.cochrane.org/cochrane-interventions-handbook]

15. Zitzmann NU, Berglundh T. Definition and prevalence of peri-implant diseases. J Clin Periodontol. 2008 Sep;35(8 Suppl):286-91. [Medline: 18724856] [doi: 10.1111/j.1600-051X.2008.01274.x]

16. Heitz-Mayfield LJ. Diagnosis and management of peri-implant diseases. Aust Dent J. 2008 Jun;53 Suppl 1:S43-8. [Medline: 18498585] [doi: 10.1111/j.1834-7819.2008.00041.x]

17. Greenstein G, Cavallaro J. Failed dental implants: diagnosis, removal and survival of reimplantations. J Am Dent Assoc. 2014 Aug;145(8):835-42. [Medline: 25082932] [doi: 10.14219/jada.2014.28] 
18. Misch CE, Perel ML, Wang HL, Sammartino G, Galindo-Moreno P, Trisi P, Steigmann M, Rebaudi A, Palti A, Pikos MA, Schwartz-Arad D, Choukroun J, Gutierrez-Perez JL, Marenzi G, Valavanis DK. Implant success, survival, and failure: the International Congress of Oral Implantologists (ICOI) Pisa Consensus Conference. Implant Dent. 2008 Mar;17(1):5-15. [Medline: 18332753] [doi: 10.1097/ID.0b013e3181676059]

19. Lindhe J, Meyle J; Group D of European Workshop on Periodontology. Peri-implant diseases: Consensus Report of the Sixth European Workshop on Periodontology. J Clin Periodontol. 2008 Sep;35(8 Suppl):282-5. [Medline: 18724855] [doi: 10.1111/j.1600-051X.2008.01283.x]

20. Lang NP, Berglundh T; Working Group 4 of Seventh European Workshop on Periodontology. Periimplant diseases: where are we now?--Consensus of the Seventh European Workshop on Periodontology. J Clin Periodontol. 2011 Mar;38 Suppl 11:178-81. [Medline: 21323713] [doi: 10.1111/j.1600-051X.2010.01674.x]

21. Froum SJ, Rosen PS. A proposed classification for peri-implantitis. Int J Periodontics Restorative Dent. 2012 Oct;32(5): 533-40. [Medline: 22754901]

22. Kadkhodazadeh M, Amid R. Evaluation of peri-implant tissue health using a scoring system. JIACD. 2012;4:51-7.

23. Sanz M, Chapple IL; Working Group 4 of the VIII European Workshop on Periodontology. Clinical research on peri-implant diseases: consensus report of Working Group 4. J Clin Periodontol. 2012 Feb;39 Suppl 12:202-6. [Medline: 22533957] [doi: 10.1111/j.1600-051X.2011.01837.x]

24. The American Academy of Periodontology (AAP). Peri-implant mucositis and peri-implantitis: a current understanding of their diagnoses and clinical implications. J Periodontol. 2013 Apr;84(4):436-43. [Medline: 23537178] [doi: 10.1902/jop.2013.134001]

25. Padial-Molina M, Suarez F, Rios HF, Galindo-Moreno P, Wang HL. Guidelines for the diagnosis and treatment of peri-implant diseases. Int J Periodontics Restorative Dent. 2014 Nov-Dec;34(6):e102-11. [Medline: 25411744] [doi: $10.11607 / \mathrm{prd} .1994]$

26. Ata-Ali J, Ata-Ali F, Bagan L. A Classification Proposal for Peri-Implant Mucositis and Peri-Implantitis: A Critical Update. The Open Dentistry Journal, 2015 Dec, 9, 393-395. [Medline: 26966463] [PMC free article: 4758051] [doi: 10.2174/1874210601509010393]

27. Ritter L, Elger MC, Rothamel D, Fienitz T, Zinser M, Schwarz F, Zöller JE. Accuracy of peri-implant bone evaluation using cone beam CT, digital intra-oral radiographs and histology. Dentomaxillofac Radiol. 2014;43(6):20130088. [Medline: 24786136] [PMC free article: $\underline{4141670]}$ [doi: 10.1259/dmfr.20130088]

28. Albrektsson T, Isidor F. Consensus report of session IV.; In: Lang NP, Karring T, editors. Proceedings of the 1st European workshop on periodontology. London: Quintessence Publishing; 1994. p. 365-9.

29. Okayasu K, Wang HL. Decision tree for the management of periimplant diseases. Implant Dent. 2011 Aug;20(4):256-61. [Medline: 21778886] [doi: 10.1097/ID.0b013e3182263589]

30. Lang NP, Wetzel AC, Stich H, Caffesse RG. Histologic probe penetration in healthy and inflamed peri-implant tissues. Clin Oral Implants Res. 1994 Dec;5(4):191-201. [Medline: 7640332] [doi: 10.1034/j.1600-0501.1994.050401.x]

31. Luterbacher S, Mayfield L, Brägger U, Lang NP. Diagnostic characteristics of clinical and microbiological tests for monitoring periodontal and peri-implant mucosal tissue conditions during supportive periodontal therapy (SPT). Clin Oral Implants Res. 2000 Dec;11(6):521-9. [Medline: 11168245] [doi: 10.1034/j.1600-0501.2000.011006521.x]

32. Jepsen S, Rühling A, Jepsen K, Ohlenbusch B, Albers HK. Progressive peri-implantitis. Incidence and prediction of peri-implant attachment loss. Clin Oral Implants Res. 1996 Jun;7(2):133-42. [Medline: 9002832] [doi: 10.1034/j.1600-0501.1996.070207.x]

33. Schou S, Holmstrup P, Stoltze K, Hjørting-Hansen E, Fiehn NE, Skovgaard LT. Probing around implants and teeth with healthy or inflamed peri-implant mucosa/gingiva. A histologic comparison in cynomolgus monkeys (Macaca fascicularis). Clin Oral Implants Res. 2002 Apr;13(2):113-26. [Medline: 11952731] [doi: 10.1034/j.1600-0501.2002.130201.x]

34. Etter TH, Håkanson I, Lang NP, Trejo PM, Caffesse RG. Healing after standardized clinical probing of the perlimplant soft tissue seal: a histomorphometric study in dogs. Clin Oral Implants Res. 2002 Dec;13(6):571-80. [Medline: 12519330] [doi: 10.1034/j.1600-0501.2002.130601.x]

35. Fransson C, Wennström J, Berglundh T. Clinical characteristics at implants with a history of progressive bone loss. Clin Oral Implants Res. 2008 Feb;19(2):142-7. [Medline: 18184340] [doi: 10.1111/j.1600-0501.2007.01448.x]

36. Vouros ID, Kalpidis CD, Horvath A, Petrie A, Donos N. Systematic assessment of clinical outcomes in bonelevel and tissue-level endosseous dental implants. Int J Oral Maxillofac Implants. 2012 Nov-Dec;27(6):1359-74. [Medline: 23189285]

37. Fransson C, Tomasi C, Pikner SS, Gröndahl K, Wennström JL, Leyland AH, Berglundh T. Severity and pattern of peri-implantitis-associated bone loss. J Clin Periodontol. 2010 May;37(5):442-8. [Medline: 20507368] [doi: 10.1111/j.1600-051X.2010.01537.x]

38. Botos S, Yousef H, Zweig B, Flinton R, Weiner S. The effects of laser microtexturing of the dental implant collar on crestal bone levels and peri-implant health. Int J Oral Maxillofac Implants. 2011 May-Jun;26(3):492-8. [Medline: 21691595]

39. Peñarrocha-Diago MA, Flichy-Fernández AJ, Alonso-González R, Peñarrocha-Oltra D, Balaguer-Martínez J, PeñarrochaDiago M. Influence of implant neck design and implant-abutment connection type on peri-implant health. Radiological study. Clin Oral Implants Res. 2013 Nov;24(11):1192-200. [Medline: 22925048] [doi: 10.1111/j.1600-0501.2012.02562.x] 
40. Song DW, Lee DW, Kim CK, Park KH, Moon IS. Comparative analysis of peri-implant marginal bone loss based on microthread location: a 1-year prospective study after loading. J Periodontol. 2009 Dec;80(12):1937-44. [Medline: 19961377] [doi: 10.1902/jop.2009.090330]

41. Lindhe J, Berglundh T. The interface between the mucosa and the implant. Periodontol 2000. 1998 Jun;17:47-54. [Medline: 10337312] [doi: 10.1111/j.1600-0757.1998.tb00122.x]

42. Al-Nawas B, Kämmerer PW, Morbach T, Ophoven F, Wagner W. Retrospective clinical evaluation of an internal tube-intube dental implant after 4 years, with special emphasis on peri-implant bone resorption. Int J Oral Maxillofac Implants. 2011 Nov-Dec;26(6):1309-16. [Medline: 22167438]

43. Linkevicius T, Puisys A, Steigmann M, Vindasiute E, Linkeviciene L. Influence of Vertical Soft Tissue Thickness on Crestal Bone Changes Around Implants with Platform Switching: A Comparative Clinical Study. Clin Implant Dent Relat Res. 2015 Dec;17(6):1228-36. [Medline: 24673875] [doi: 10.1111/cid.12222]

44. Ivanoff CJ, Gröndahl K, Sennerby L, Bergström C, Lekholm U. Influence of variations in implant diameters: a 3- to 5-year retrospective clinical report. Int J Oral Maxillofac Implants. 1999 Mar-Apr;14(2):173-80. [Medline: 10212533] [doi: 10.1097/00008505-199904000-00010]

45. Vigolo P, Givani A. Platform-switched restorations on wide-diameter implants: a 5-year clinical prospective study. Int J Oral Maxillofac Implants. 2009 Jan-Feb;24(1):103-9. [Medline: 19344032]

46. Fickl S, Zuhr O, Stein JM, Hürzeler MB. Peri-implant bone level around implants with platform-switched abutments. Int J Oral Maxillofac Implants. 2010 May-Jun;25(3):577-81. [Medline: 20556258]

47. Lee SY, Piao CM, Koak JY, Kim SK, Kim YS, Ku Y, Rhyu IC, Han CH, Heo SJ. A 3-year prospective radiographic evaluation of marginal bone level around different implant systems. J Oral Rehabil. 2010 Jul;37(7):538-44. [Medline: 20406355] [doi: 10.1111/j.1365-2842.2010.02083.x]

48. Kumar VV, Sagheb K, Kämmerer PW, Al-Nawas B, Wagner W. Retrospective Clinical Study of Marginal Bone Level Changes with Two Different Screw-Implant Types: Comparison Between Tissue Level (TE) and Bone Level (BL) Implant. J Maxillofac Oral Surg. 2014 Sep;13(3):259-66. [Medline: 25018598] [PMC free article: 4082557] [doi: 10.1007/s12663-013-0532-5]

49. Stein AE, McGlmphy EA, Johnston WM, Larsen PE. Effects of implant design and surface roughness on crestal bone and soft tissue levels in the esthetic zone. Int J Oral Maxillofac Implants. 2009 Sep-Oct;24(5):910-9. [Medline: 19865632]

50. Norton MR. Multiple single-tooth implant restorations in the posterior jaws: maintenance of marginal bone levels with reference to the implant-abutment microgap. Int J Oral Maxillofac Implants. 2006 Sep-Oct;21(5):777-84. [Medline: $\underline{17066640]}$

51. Kühl S, Zürcher S, Zitzmann NU, Filippi A, Payer M, Dagassan-Berndt D. Detection of peri-implant bone defects with different radiographic techniques - a human cadaver study. Clin Oral Implants Res. 2016 May;27(5):529-34. [Medline: 26059443] [doi: 10.1111/clr.12619]

52. García-García M, Mir-Mari J, Benic GI, Figueiredo R, Valmaseda-Castellón E. Accuracy of periapical radiography in assessing bone level in implants affected by peri-implantitis: a cross-sectional study. J Clin Periodontol. 2016 Jan;43(1): 85-91. [Medline: 26660842] [doi: 10.1111/jcpe.12491]

53. Wilson TG Jr. The positive relationship between excess cement and peri-implant disease: a prospective clinical endoscopic study. J Periodontol. 2009 Sep;80(9):1388-92. [Medline: 19722787] [doi: 10.1902/jop.2009.090115]

54. Hämmerle $\mathrm{CH}$, Brägger U, Bürgin W, Lang NP. The effect of subcrestal placement of the polished surface of ITI implants on marginal soft and hard tissues. Clin Oral Implants Res. 1996 Jun;7(2):111-9. [Medline: 9002829] [doi: 10.1034/j.1600-0501.1996.070204.x]

55. Tarnow DP, Cho SC, Wallace SS. The effect of inter-implant distance on the height of inter-implant bone crest. J Periodontol. 2000 Apr;71(4):546-9. [Medline: 10807116] [doi: 10.1902/jop.2000.71.4.546]

56. Gallucci GO, Grütter L, Chuang SK, Belser UC. Dimensional changes of peri-implant soft tissue over 2 years with single-implant crowns in the anterior maxilla. J Clin Periodontol. 2011 Mar;38(3):293-9. [Medline: 21219391] [doi: $\underline{10.1111 / \text { j.1600-051X.2010.01686.x] }}$

\section{To cite this article:}

Ramanauskaite A, Juodzbalys G.

Diagnostic Principles of Peri-Implantitis: a Systematic Review and Guidelines for Peri-Implantitis Diagnosis Proposal

J Oral Maxillofac Res 2016;7(3):e8

URL: http://www.ejomr.org/JOMR/archives/2016/3/e8/v7n3e8.pdf

doi: $10.5037 /$ jomr.2016.7308 
Copyright (C) Ramanauskaite A, Juodzbalys G. Published in the JOURNAL OF ORAL \& MAXILLOFACIAL RESEARCH (http://www.ejomr.org), 9 September 2016.

This is an open-access article, first published in the JOURNAL OF ORAL \& MAXILLOFACIAL RESEARCH, distributed under the terms of the Creative Commons Attribution-Noncommercial-No Derivative Works 3.0 Unported License, which permits unrestricted non-commercial use, distribution, and reproduction in any medium, provided the original work and is properly cited. The copyright, license information and link to the original publication on (http://www.ejomr.org) must be included. 